\title{
Refugee Policy as Border Governance: Refugee Return, Peacebuilding and Myanmar's Politics of Transition
}

Kirsten McConnachie, University of East Anglia, k.mcconnachie@uea.ac.uk

\begin{abstract}
This article examines the relationship between refugee policy and peacebuilding in Myanmar and argues for recognition of refugee policy as an influence on national politics and the politics of transition. Refugees have largely been overlooked in analyses of Myanmar's transition, apparently considered peripheral to more prominent topics such as negotiation with armed groups, economic reform and political elections. By analysing approaches to return and repatriation in three distinct contexts (refugees in camps in Thailand, Rohingya refugees in Bangladesh and Chin refugees in Malaysia) this article reveals the ways in which refugee policy reproduce boundaries and power hierarchies at multiple levels. It is argued that proposals for return and repatriation of refugees to Myanmar enact "border governance" at three scales: (1) global border control by keeping refugees in their region of origin or returning them to their country of origin; (2) national border control by reinforcing boundaries between Myanmar and its surrounding states; and (3) the governance of political transition by reinforcing the Myanmar Government's narrative of peacebuilding by recasting continuing conflict as conditions suitable for refugee return. This latter point is particularly significant for refugees as it both encourages donor withdrawal from refugee situation and strengthens the Myanmar State against ethnic opposition movements.
\end{abstract}




\section{Introduction 1}

Since Myanmar began a process of political liberalisation in 2010, refugees outside the country have found themselves under increasing pressure to return. This has been the case across diverse contexts of asylum, including refugees living in camps in Thailand, Rohingya in Bangladesh, and ethnic Chin in India and Malaysia. Return of refugees from these countries has been supported (and in some cases instigated) by international donors and agencies under the auspices of peacebuilding, even though the political reality inside Myanmar is of a stalled peace process, continued conflict and state violence. The promotion of return in these circumstances has considerable personal costs for refugees, in risks to security as well as the emotional toll of uncertainty and disempowerment in decision-making. I argue that it also has more far-reaching political consequences as efforts to repatriate refugees have the effect of reinforcing the Myanmar's government's narrative of transition and transformation over the political reality of continuing conflict and oppression. This has implications for peacebuilding (by favouring the government and weakening other political actors) and statebuilding (by normalising the political repression and military dominance that has caused displacement from Myanmar for so many years).

The analysis presented here is drawn from more than ten years' research with refugees from Myanmar (including substantial periods of fieldwork with refugee communities and extensive

\footnotetext{
${ }^{1}$ I am grateful to the University of Warwick School of Law for supporting the workshop on Border Governance in April 2018 at which this paper was first presented, and to all the participants in that workshop for their comments and contributions. Sincere thanks also to the audience at the Refugee Law Initiative public seminar in February 2019 and to Norbert Peabody and the peer reviewers at Modern Asian Studies for comments that have informed and improved the final article.
} 
qualitative interviews with a range of stakeholders in Thailand between 2008 and 2014 and in Malaysia and India between 2012 and 2016) and continuing relationships with displaced communities and civil society in these countries. My most recent field trip was to Thailand in 2018 and included visits with refugee activists and community based organisations in Chiang Mai, Mae Sariang and Mae La Oon refugee camp. Some data from those interviews is included in this article.

The central contention of this article is that while refugee policy is rarely discussed in analyses of international peacebuilding and statebuilding, it nevertheless has the potential to influence political governance at multiple scales. This argument is presented in three stages. First, an overview of recent politics in Myanmar and the "triple transition" of economic liberalisation, democratic transition and peace process between the Government and ethnic armed organisations. Second, an explanation of refugee repatriation in international policy and practice, and the case studies of proposed refugee return to Myanmar: "facilitated voluntary return" of refugees from Thailand; repatriation of Rohingya refugees from Bangladesh; and the cessation of refugee status for Chin refugees. Third, the effects of these policies are analysed in relation to their personal consequences for refugees and their national and international political influence. It is argued that this represents "border governance" at multiple scales, with implications for global border control, national border control and the governance of political transition. Recognising these roles and effects has a number of implications, including to show that the relationship between refugee policy and national politics is not one-way (i.e., that refugees are affected by events in their country of origin) but that repatriation planning can itself be an intervention in national and international affairs. 


\section{Myanmar in transition}

Myanmar was under military rule from 1962, and after the violent suppression of prodemocracy protests in 1988 was largely closed off to the wider international community. Throughout those years, and indeed until the present, Myanmar has consistently generated internal and cross-border forced migration. An important driver of forced migration has been Myanmar's politics of ethnicity and identity. Myanmar is ethnically diverse, with an estimated two-thirds of the population of Bamar [Burman] ethnicity and one-third of non-Bamar ethnicity. The importance of ethnicity to Myanmar's national politics is reflected in its administrative division into eight regions (where the majority population is of Bamar ethnicity) and seven states where the majority population is a non-Bamar ethnic group (Chin, Kachin, Kayah [Karenni], Kayin [Karen], Mon, Rakhine and Shan). Ethnicity is at the centre of Myanmar's constitutional law, with citizenship predicated on inclusion in a list of 135 "national races". The exclusion of Rohingya from this list is a central contributing factor to their exclusion and persecution in recent decades. ${ }^{2}$

Myanmar's politics post-independence (and particularly post-1962) have been dominated by Bamar nationalism and an agenda of "Burmanisation" that emphasises the superiority of Bamar ethnicity, Burmese language and Buddhist faith. For non-Bamar ethnic groups this has led to discrimination in access to services and development, religious discrimination against nonBuddhists (including Christians and Muslims), and ultimately to conflict between ethnic armed organisations and the Myanmar military. It is this climate of discrimination, persecution and political violence that has caused so much internal and cross-border displacement for so many

\footnotetext{
${ }^{2}$ N. Cheesman (2017) How in Myanmar 'National Races' Came to Surpass Citizenship and Exclude Rohingya. Journal of Contemporary Asia Vol. 47, no. 3, pp.461-483.
} 
years. There are large populations of refugees from Myanmar in Bangladesh, India, Malaysia and Thailand, and at least 600,000 people internally displaced within Myanmar. ${ }^{3}$

Under military rule, Myanmar was a pariah on the international stage. This was rapidly reversed when Myanmar embarked on political reforms in 2010. Aid and investment flooded in even while the military remained in power. More than US\$10bn in international aid was disbursed in Myanmar between 2011 and 2015 and aid accelerated after the installation of the NLD-led government in 2015. ${ }^{4}$ The EU alone provided almost one billion euro to Myanmar from 2012-2020..$^{5}$ In 2012, the World Bank characterised Myanmar as undergoing a "triple transition": from military rule to democracy; from conflict in ethnic territories to peace; from a centrally managed economy to a market economy. ${ }^{6}$ By 2020 , the depth of these transitions was questionable. Economic reforms had driven a massive rise in GDP, which almost doubled

\footnotetext{
${ }^{3}$ In April 2020, the most recent UNHCR figures counted 859,808 refugees and asylum seekers from Myanmar in Bangladesh; 178,990 in Malaysia; and 93,227 refugees in camps in Thailand (see https://data2.unhcr.org/en/situations). These figures likely underestimate the true population in each case. In 2018, the IDMC estimated that there were 401,000 internally displaced persons in Myanmar; more than 200,000 fewer than its 2017 estimate of 635,000 . The reason for this reduction is not clear. IDMC notes that "TBC released a comprehensive report on internal displacement in south-eastern Myanmar in 2018, its first since 2012. The updated figure for this region indicates that there are fewer IDPs in the region than there were in 2012. This lower estimate for south-eastern Myanmar is the main factor in IDMC's 2018 estimate being nearly 234,000 lower than in 2017. It is unclear, however, if TBC's figure decreased mainly due to its reduced coverage of Shan South or because of new resettlements and returns." IDMC Figure Analysis for 2018 available at http://www.internal-displacement.org/countries/myanmar [accessed 21st April 2020]

${ }^{4}$ T. Carr (2018), Supporting the Transition: Understanding Aid to Myanmar Since 2011. Asia Foundation ${ }^{5}$ European Court of Auditors (2018), Special Report: EU Assistance to Myanmar/Burma. European Union. p 9.

${ }^{6}$ The term "triple transition" was coined by the World Bank in its Interim Strategy Note for Myanmar(2012).
} 
between 2009 and 2017. ${ }^{7}$ The political landscape was less encouraging. Despite highly visible milestones such as the 2015 elections and installation of an NLD-led government, the military continues to hold a constitutionally-protected role in governance. Furthermore, the new government has retained or escalated many of the military's repressive policies, including restricting international aid to internally displaced people and policing assembly and expression. Some commentators have questioned whether the real political transition is not to democracy but autocracy, i.e. the normalisation and institutionalisation of the military's role in Myanmar's politics. ${ }^{8}$ In January 2019, the UN Special Rapporteur on the Situation of Human Rights in Myanmar concluded that, "instead of bringing about the democratic reforms that were promised, the civilian government is consolidating what military governments worked towards for many years." 9

The risk of autocracy or "military-state capture" 10 is particularly acute in relation to the peace process with ethnic armed organisations. A lasting peace in Myanmar will only be achieved if the root causes of conflict in ethnic states are addressed: the discrimination, underdevelopment, military violence and impunity that underlie ethnic demands for federalism and political autonomy. This would also require amending the 2008 Constitution and beginning the work of rebalancing power between military and Government as well as between Bamar and non-

\footnotetext{
${ }^{7}$ From US\$36.9 billion to US\$67.07 billion World Bank Myanmar Country Data available at https://data.worldbank.org/country/myanmar [accessed 21st April 2020]

${ }^{8}$ K. Stokke, R. Vakulchuk, I. Øverland (2018) Myanmar: A Political Economy Analysis, Oslo: Norwegian Ministry of Foreign Affairs.

${ }^{9}$ UN Office of the High Commissioner for Human Rights (2019) End of mission statement by the Special Rapporteur on the situation of human rights in Myanmar. 25 ${ }^{\text {th }}$ January 2019.

${ }^{10}$ Stokke et al,(2018) Myanmar: A Political Economy Analysis, Oslo: Norwegian Ministry of Foreign Affairs, p. xi.
} 
Bamar ethnic groups. The peace process has to date made little progress towards these goals, despite a "Nationwide Ceasefire Agreement" (currently with ten signatory ethnic armed organisations) and the " $21^{\text {st }}$ Century Panglong” Peace Conference (convened in 2016, 2017 and 2018). ${ }^{11}$

While the peace process has failed to deliver concrete outcomes, the Myanmar Army has continued to target ethnic territories. Ceasefires have been repeatedly violated in Chin State and Karen State. In Kachin and Shan States, where no ceasefire has been agreed, the army has used air strikes against civilian populations. ${ }^{12}$ Extreme violence against Rohingya and other Muslim communities culminated in a "human rights catastrophe" in Rakhine State in 2017. An independent UN Fact-Finding mission found that human rights violations since 2012 "undoubtedly amount to the gravest crimes under international law" and that "these abusive patterns are reflective of the situation in Myanmar as a whole."13 Exceptionally, there are cases

\footnotetext{
$\overline{11}$ The original signatories were: Karen National Union; Karen National Liberation Army-Peace Council; Democratic Karen Buddhist Army; Arakan Liberation Party; All-Burma Students Democratic Front; Chin National Front; Pa-O National Liberation Organisation; Restoration Council Shan State. New Mon State Party and Lahu Democratic Union signed in February 2018.

${ }^{12}$ Furthermore, the NCA offers little to address the needs of refugees and displaced people. Displacement is mentioned in Article 10 on "the provision of humanitarian assistance", with reference to coordination between government ministries, EAOs and local organisations in the delivery of humanitarian assistance and requiring that they "ensure the safety and dignity of the IDPs when undertaking a prioritised voluntary return of IDPs to their places of origin or resettlement of IDPs into new villages in suitable areas" and (c) "Collaborate on the resettlement process including verification of IDPs and refugees." Full-text of the NCA is available at Myanmar Peace Monitor http://www.mmpeacemonitor.org/1499 [accessed 21 st April 2020]

${ }^{13}$ Human Rights Council (2018), Report of the independent international fact-finding mission on Myanmar, A/HRC/39/64, para 100-117.
} 
pending against Myanmar before both the International Court of Justice (which at the request of The Gambia has already ordered provisional measures to prevent genocide against Rohingya in Myanmar) and the International Criminal Court (which is investigating alleged crimes of deportation and persecution committed in Rakhine State, where there is a jurisdictional nexus to Bangladesh, a state party to the Rome Statute of the International Criminal Court). ${ }^{14}$

Two distinct narratives have emerged to interpret Myanmar's politics post-liberalisation. One has accepted the "triple transition" at face value and recognised the Government as an honest broker in pursuing political and economic reform, and peace with ethnic armed organisations. This version of events perceives continuing problems in the country as developmental rather than political and the best course of action for the international community as to support the Government in its pursuit of political transition. This has been the approach taken by governments and international agencies such as UNDP and USAID (among many others) who have invested significantly in Myanmar, channelling all aid through the Government in order to "strengthen Burman's transition to democracy". ${ }^{15}$ The second narrative considers that there is no transition or at best a very weak transition: that the Government is either unwilling or unable to produce real change in its relations with ethnic minorities, that the military continues to dictate national politics, and that Myanmar remains a country at war. From this perspective, approaching the Government as the only legitimate political authority in the country provides it with unearned political legitimacy (as well as an aid bonanza) and undermines other actors

\footnotetext{
${ }^{14}$ Application of the Convention on the Prevention and Punishment of the Crime of Genocide (The Gambia v Myanmar), Order of Provisional Measures, 23 ${ }^{\text {rd }}$ January 2020; Decision Pursuant to Article 15 of the Rome Statute on the Authorisation of an Investigation into the Situation in the People's Republic of Bangladesh/Republic of the Union of Myanmar ICC-01/19-27.

${ }^{15}$ See USAID, Where we Work: Burma at usaid.gov/burma. [accessed $21^{\text {st }}$ April 2020]
} 
in the peace process. This view has been represented by some researchers and academics particularly those working on issues of ethnic politics - and is very much the prevailing opinion among ethnic armed organisations and refugee communities. ${ }^{16}$

International donors, investors and humanitarian agencies have continued to work through and with the Myanmar Government despite evidence of repression, persecution and pervasive military impunity. ${ }^{17}$ There has been a tendency for international actors to flatten political understanding of Myanmar's ethnic conflicts, focusing on developmental questions and giving insufficient weight to the historical context of discrimination and oppression. This is a classic illustration of Ferguson's description of international development as an "anti-politics machine" ${ }^{18}$ A lack of contextual political understanding of Myanmar's historic and current conflicts bolsters an "over-reliance on developmental engagement strategies", described by

\footnotetext{
${ }^{16}$ E.g. D. Brenner and S. Schullman (2019) Myanmar's Top-Down Transition: Challenges for Civil Society. IDS Bulletin Vol. 50, no.3, pp. 17-36.

${ }^{17}$ E.g. Burma Campaign UK's evidence to the House of Commons International Development Select Committee in October 2011 available at https://publications.parliament.uk/pa/cm201012/cmselect/cmintdev/1569/1569vw02.htm [accessed 7th November 2019] "DFID and the rest of the international community do not do enough to challenge the restrictions on humanitarian assistance imposed by the government of Burma. Restrictions are routinely raised in meetings, but tend to be one of many talking points. There is no coordinated international pressure on this issue." The preference of senior UN officials and the UN Mission to engage the Myanmar Government rather than challenge its actions is analysed in G. Rosenthal (2019), A Brief and Independent Enquiry into the Involvement of the United Nations in Myanmar 2012-2018, available at
} https://www.un.org/sg/sites/www.un.org.sg/files/atoms/files/Myanmar\%20Report\%20-\%20May\%202019.pdf [accessed 21 ${ }^{\text {st }}$ April 2020]

${ }^{18}$ J. Ferguson (1994) The Anti-Politics Machine: Development, Depoliticization and Bureaucratic Power in Lesotho, Minneapolis: University of Minnesota Press. 
Stokke et al as a key risk of international aid programmes that may actually undermine peace and democracy in Myanmar. ${ }^{19}$ Civil society activists have claimed that international donors have affected the balance of power in peace negotiations and "significantly weakened the negotiating power of the ethnic groups" by uncritically accepting the official narrative of transition, and particularly by distributing all international aid through the Government. ${ }^{20}$ Paul Sein Twa explains that:

“They [international actors] approach the situation as a normal case of statebuilding, which works in favour of the government's unitary system. The narrative is that poverty and the weaknesses of the government administration are behind the problems in Myanmar, while the root causes are actually political. The international community wants the NCA [Nationwide Ceasefire Agreement] to be signed no matter if the deal is good or bad for ethnic groups."21

This article argues that refugee policy has occupied a similar and thus far unrecognised role as a political intervention into Myanmar's peace process that favours the government and undermines other political actors. Since the earliest stages of Myanmar's political reforms, refugees from camps in Thailand have been encouraged to return. More recently, this has been accompanied with international support for repatriation of Rohingya from Bangladesh; and a

\footnotetext{
${ }^{19}$ Stokke et al, ibid, p. xix.

${ }^{20}$ P. Sein Twa (2013), Inclusivity and the peace process in Burma/Myanmar - perspectives of an ethnic leader and a civil society activist, Development Dialogue pp. 119-130, at p. 130. Available at:

http://www.daghammarskjold.se/wp-content/uploads/2016/01/DHF_DD63_p119-130.pdf [Accessed 20th April 2020]

${ }^{21}$ P. Sein Twa, ibid.
} 
declaration of cessation of international protection for Chin refugees from Myanmar (issued in June 2018 and revoked in March 2019). With the exception of the Rohingya, these cases have attracted little international attention. These proposals have important implications in terms of their compliance with international refugee law (such as the requirement of voluntariness in repatriation or the threshold for declaring ceased circumstances giving rise to refugee protection). They also have significant political implications. What are the consequences of supporting the government and military narrative of reform over refugees' and citizens' lived experiences of violence? Whether the country is safe for refugee return is a question with obvious and immediate consequences for refugees, but also for Myanmar's national politics, for the role of ethnic organisations in the peace process and ultimately the position of ethnic minorities in the future of Myanmar.

\section{Repatriation in principle and practice}

Voluntary repatriation (i.e. return of refugees to their country of origin) is one of three recognised durable solutions to refugee situations, along with local integration in the host country and resettlement from the host country to a third country. Repatriation is frequently described by the United Nations High Commissioner for Refugees (UNHCR) as "the preferred solution" for refugees, though it may be more accurate to say that it is the preferred solution for states. As a result, it is also the durable solution used for the largest number of refugees: by 2010, UNHCR had assisted in the repatriation of nearly 25 million refugees. ${ }^{22}$ To be a durable solution, repatriation should offer a genuine end to displacement and a restoration of state protection. International standards to ensure the legitimacy of repatriation require that it is

\footnotetext{
${ }^{22}$ K. Long (2013), Back to Where You Once Belonged: A historical review of UNHCR Policy and Practice on Repatriation, UNHCR Policy and Evaluation Unit, p. 1.
} 
voluntary (i.e. an individual choice) and that it is carried out "in safety and with dignity". ${ }^{23} \mathrm{As}$ repatriation has become the "preferred solution" these thresholds are often applied weakly if at all, and the decision to repatriate is not determined by individual refugees but by international agencies and donors. ${ }^{24}$

Repatriation is the act of returning refugees from one state to another across a defined national border. More than this, repatriation is understood as returning refugees to their place of belonging, their country of citizenship where they will receive state protection. Drawing on Mary Douglas' analysis of social ordering in Purity and Danger, Malkki famously described refugees as "matter out of place" in a world of sovereign states. ${ }^{25}$ Repatriation ostensibly corrects this category error by, quite literally, putting refugees back in their place. By participating in repatriation, refugees are moving from conflict to peace in a spatial process of return which maps onto the political process of transition. A link between repatriation and peacebuilding has been explicitly asserted, at times as a direct and linear relationship, i.e.

\footnotetext{
${ }^{23}$ See, e.g. UNHCR (2004) Handbook for Repatriation and Reintegration Activities; (1996) Handbook on Voluntary Repatriation. Repatriation is envisaged in the 1951 Convention on the Status of Refugees and in the 1950 Statute of the UNHCR. "Voluntary" is specified only in UNHCR Statute. It was also used in General Assembly Resolution 8(1) on the Question of Refugees (1946) and in countless UNHCR texts and documents thereafter.

${ }^{24}$ J. Crisp and K. Long (2018) Safe and Voluntary Refugee Repatriation: From Principle to Practice, JMHS 4(3): $141-147$.

${ }^{25}$ L. Malkki (1992), National Geographic: The Rooting of Peoples and the Territorialization of National Identity among Scholars and Refugees, Cultural Anthropology Vol. 7, no. 1, pp. 22-44 at p. 34. M. Douglas (2002 [1966]), Purity and Danger, Abingdon: Routledge Classics.
} 
"peacebuilding with people" or "peace by repatriation". ${ }^{26}$ UNHCR policies have reinforced that approach by emphasising repatriation as one stage in a larger process of personal and political transformation. For example, in the early 2000s, UNHCR's so-called "4Rs" approach (repatriation, reintegration, rehabilitation, reconstruction) directly positioned repatriation as a tool of peacebuilding. This approach is no longer part of the agency's vocabulary, though the notion of repatriation extending beyond the act of return and into longer-term processes of reintegration remains very much alive. ${ }^{27}$

A relationship between repatriation and peacebuilding has been repeatedly asserted but without much consideration of what such a relationship might say about the type of peace that is being built. ${ }^{28}$ Analysing refugee returns in the 1990s, he observed that a language of peacebuilding was being used to legitimise repatriation as a tool for containment of refugees rather than protection. ${ }^{29} \mathrm{He}$ argued that this was not incidental but deliberate; that peacebuilding as a conceptual category was invented to "blur the distinction between war and peace" and normalise ongoing violence as "transition" rather than conflict. This creates a number of

\footnotetext{
${ }^{26}$ P. Johansson (2010), Peace by Repatriation: Concepts, cases and conditions, Doctoral thesis University of Umeå; S. Albert (1997) The Return of Refugees to Bosnia-Herzegovina: Peacebuilding with People, International Peacekeeping Vol. 4, no. 3, pp1-23.

${ }^{27}$ The "Four Rs" approach is set out in UNHCR (2003), Framework for durable solutions for refugees and persons of concern. The current approach is set out in UNHCR (2008) UNHCR's role in support of the return and reintegration of displaced populations: policy framework and implementation strategy. Thanks to Jeff Crisp for clarifying this point.

${ }^{28}$ S. Ogata (1997), Refugee Repatriation and Peacebuilding, Refugee Survey Quarterly Vol. 16, no 2, pp1-4.

${ }^{29}$ B.S. Chimni (2002) Post-conflict peace-building and the return of refugees: Concepts, practices and institutions in E. Newman, ed. Refugees and Forced Displacement, United Nations University Press, pp197-8.
} 
political and economic opportunities for states: allowing global investment and structural adjustment programmes to be launched, circumscribing the meaning of "peacebuilding" by equating it with a rudimentarily accountable state, and thereby condoning donor withdrawal from protracted refugee situations and the return of refugees. Chimni's position that international peacebuilding has not only failed to prevent but actively legitimated the premature return of refugees is firmly relevant to current circumstances in Myanmar, where (as I explain below) international donors have disengaged from protracted refugee situations, invested heavily in Myanmar's domestic economy, and shown a marked lack of interest in demanding accountability for massive, ongoing human rights violations. Encouraging repatriation in these circumstances enables containment of refugees and prioritises national and international political interests above refugee protection. It is also an intervention into Myanmar's national politics, endorsing the state narrative of transition over the direct experience of refugees and other victims of state violence. This serves to strengthen the state politically and thereby to weaken opposition actors, including ethnic armed organisations.

The discussion below examines three policies aimed at the return of refugees to Myanmar: facilitated voluntary returns of refugees from Thailand; proposed mass repatriation of Rohingya refugees from Bangladesh; UNHCR's declaration of cessation of international refugee protection for Chin refugees (issued in June 2018 and revoked in March 2019). Refugees in these countries have very different living conditions and levels of acceptance and recognition in their countries of asylum. They also come from ethnic groups which have very different experiences of and potential for peacebuilding in Myanmar. Yet they have all been treated similarly by UNHCR and other international agencies and donors, which have 
supported and promoted return to Myanmar despite the political realities of continuing conflict, massive human rights violations and "military-state capture". 30

\section{Facilitated Voluntary Repatriation" of refugees in camps in Thailand}

Around 100,000 refugees from Myanmar are currently living in camps along the ThaiMyanmar border. These camps have existed for more than thirty-five years, and have provided refuge primarily for people fleeing conflict and persecution in southeast Myanmar, particularly Karen and Karenni States. ${ }^{31}$ Refugees in Thailand received substantial international support during the years of military rule. Indeed, when external aid was restricted to Myanmar, refugees in Thailand were one of the primary symbols of military brutality and international support for democratic and ethnic opposition movements. These were years when the camps received considerable assistance from international donors as well as informal assistance from international volunteers.

Despite this history of international support to refugees, repatriation planning began at the onset of political reforms. UNHCR established institutional mechanisms for coordinating voluntary repatriation by 2012. In October 2014, UNHCR published its Strategic Roadmap for Voluntary Repatriation, which distinguished three types of repatriation: spontaneous (organised by refugees without assistance), facilitated (UNHCR involved through provision of information and possible assistance during voluntary returns) and promoted (UNHCR providing support

\footnotetext{
${ }^{30}$ Stokke et al, ibid.

${ }^{31}$ In February 2018 the verified caseload receiving rations in the camps was 93,587. The population verified by

UNHCR was 100,015 . See monthly population updates at www.theborderconsortium.org.
} 
for transport and a package of reintegration assistance). The Strategic Roadmap viewed repatriation as part of Myanmar's political transformation and predicted that "in the most likely scenario", a Nationwide Ceasefire Agreement would be concluded in the latter half of 2014, promoted returns would begin in early 2015 and repatriation would be complete by 2017 . Promoted returns would occur "once the conditions are appropriate for the promotion of return throughout South-East Myanmar". When it became apparent that these conditions were far from being realised, UNHCR revised its approach from organised repatriation to "facilitated voluntary repatriation". Voluntary Repatriation Centres were established in every camp and regular information sessions were held to educate refugees about return options and the support that UNHCR would provide (transport back to Myanmar, 3-6 months food assistance, a mosquito net and a hygiene pack). ${ }^{32}$ The first "facilitated" repatriation was carried out in 2017 between UNHCR, the Government of Thailand and the Government of Myanmar. Notably, refugee representatives and camp committees were not included in the design and implementation of these returns. Only 65 people participated. Their reports back to the camps claimed that no arrangements had been made for access to services including education and health, and that 17 people returned to Yangon had no housing on arrival. UNHCR publicity material presented a very different story, of successful returns and happy returnees, and posted laminated printouts of these stories around the refugee camps to encourage others to follow. ${ }^{33}$

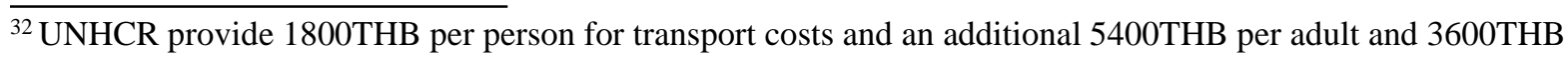
per child. Sa Isue (2018) Thailand Transfers 93 Returning Refugees to Burma Government, Karen News $9^{\text {th }}$ May 2018.

${ }^{33}$ V. Tan (2017), From camp to city, Myanmar returnees grapple with Yangon life, UNHCR news, $10^{\text {th }}$ May 
Three further repatriations were carried out in 2018 and 2019. ${ }^{34}$ By July 2019, a total of 1039 people (273 households) had participated in the voluntary repatriation programme. ${ }^{35}$

Studies and surveys among refugees from Thailand have consistently found that they do not believe conditions are suitable for sustainable returns, giving a variety of reasons for this assessment: lack of confidence in the peace process; fears for safety on return, with risks perceived from the Myanmar army and non-state armed groups; landmines in return areas; lack of houses, lands or jobs to return to; lack of documentation of Myanmar citizenship or of property ownership. ${ }^{36}$ UNHCR estimates that 15,000 people have returned "spontaneously" without notifying UNHCR. ${ }^{37}$ There is evidence to suggest that these might be best understood as a coping strategy of "cyclical return", in which families are sending one or more members back to Myanmar to 'test the waters', while keeping open the possibility of return to Thailand should conditions change. ${ }^{38}$ Furthermore, these returnees have foregone cash and transport

\footnotetext{
${ }^{34}$ Assawin Pinitwong, Karen Refugees Return to Myanmar, Bangkok Post, $1^{\text {st July }} 2019$

${ }^{35}$ UNHCR Thailand (2019) Facilitated Voluntary Repatriation - Summary, $11^{\text {th }}$ July 2019.

${ }^{36} \mathrm{~K}$. Joliffe (2015), Refugee decision-making processes, community-based protection and potential voluntary repatriation to Myanmar, available at http://www.burmalibrary.org/docs21/Jolliffe-2015-01-Refugee-decisionmaking-processes-community-based-protection-and-potential-repatriation-to-Myanmar-Jolliffe-red-.pdf
} [accessed 21 $1^{\text {st }}$ April 2020] Burma Partnership (2012), The Situation of Refugees on the Thai-Burma Border; V. Jack (2016), Communication of information on the Thai-Burma border, Forced Migration Review 52: 96-98; Progressive Voice (2019), There is No One Who Does Not Miss Home: A Report on Protracted Displaced Due to Armed Conflicts in Burma/Myanmar; M. Rudolf, C. Schmitz-Pranghe (2018) Beyond Aid: The continuous struggle to cope with displacement in Myanmar and Thailand Bonn: Bonn International Centre for Conversion. ${ }^{37}$ This number is provided on UNHCR Thailand's webpage at unhcr.or.th/en/about/Thailand [accessed $21^{\text {st }}$ April 2020].

${ }^{38}$ Rudolf and Schmitz-Pranghe, ibid, p28. 
assistance to avoid registering with the Myanmar Government; in itself, a sign of lack of confidence in the new regime.

Refugees do not want to go back to Myanmar but life in camps in Thailand is increasingly difficult. Several donors have stopped or reduced support to refugees, often while opening new programmes inside Myanmar. In several cases this has been directly linked to the peace process. Both the UK and Norwegian Governments - historically major donors to these refugee camps - opted to invest heavily in peacebuilding and reduce refugee funding accordingly. ${ }^{39}$ The primary provider of food and shelter in these refugee camps, The Border Consortium, saw its funding drop by 50 per cent between 2012 and 2016. Funding cuts have affected programmes and services throughout the camps. The Border Consortium has repeatedly reduced food rations since 2012, stopped funding internally displaced persons in 2017 , and suggested that in 2020 it will stop funding all camp staff..$^{40}$ Refugee-led systems of governance and service provision that have been built up over decades are crumbling due to lack of resources. Camp-based schools have started charging high fees or closing entirely. Some donors have pressured schools to relocate to Myanmar and made future funding conditional on

\footnotetext{
${ }^{39}$ The UK Department for International Development escalated its budget to support peacebuilding in Myanmar (£50.5 million from 2015-2020, with an escalating annual spend) while reducing support to refugees and displaced persons ( $£ 36.8$ million pledged from 2012-2018, declining to an annual spend of $£ 1$ million in 2018). Available at https://devtracker.dfid.gov.uk/countries/MM/projects (accessed 7 November 2019). On Norway’s investment in peacebuilding see C. Johnson and M. Lidauer (2014), Testing Ceasefires, Building Trust: Myanmar Peace Support Initiative Operational Review, Norwegian Ministry of Foreign Affairs.

${ }^{40}$ Karen News (2019), First it was funding cuts to food, education, healthcare and social work - now 1,000 administration workers to feel donors' razor. Karen News $20^{\text {th }}$ June 2019; HART (2017), 'Update: Shan refugee camp runs out of food', https://www.hart-uk.org/news/update-shan-refugee-camp-runs-food/. [accessed $21^{\text {st }}$
} April 2020] 
doing so. ${ }^{41}$ Services for refugees and migrants outside camps, such as the internationallyrenowned Mae Tao Clinic, have also been affected. UNHCR in Thailand claims it has not encouraged people to return but merely provided "necessary assistance" to those who want to return. ${ }^{42}$ Refugees perceive it differently, viewing the creation of Voluntary Repatriation Centres, cuts to services, and repeated "preferences surveys" as pressure to return that is eroding the voluntary nature of repatriation. These views came through very clearly when I visited Mae La Oon in May 2018, when every person that I spoke with emphasised their fear of return and anxiety for the future:

“In camp because of the noise of 'return, return', we worry. We talk a lot what will we do. I am still traumatised from running away from fighting. The noise of shooting is still in my ears. When will we have to go back? When? I cannot sleep. I worry. I cannot imagine if I have to go back." ${ }^{43}$

"I am already tired from running in the jungle. I don't want to see Burma Army any more. I am already afraid. My family have told me that women are raped by the Burma Army. If we are lucky we will live. If we not lucky we will die. It would be better to die [i.e. commit suicide] than return." 44

\footnotetext{
$\overline{{ }^{41} \text { Interviews in Thailand in } 2^{\text {nd }} \text { May }}$ 2018; also S. Oh and M. Walker (2019) 'Hanging in the Balance:

Challenges in Relocating a Post-secondary School from a Thai Refugee Camp to a Ceasefire area in Myanmar' Tea Circle Oxford.

${ }^{42}$ Nan Wai Phyo Zar, UNHCR says it has never encouraged refugees to return home from Thai border, Karen News $27^{\text {th }}$ June 2018.

${ }^{43}$ KWO member, Mae La Oon refugee camp, $3^{\text {rd }}$ May 2018

${ }^{44}$ Participant in women's focus group, Mae La Oon refugee camp, Thailand, $4^{\text {th }}$ May 2018.
} 
UNHCR was widely perceived as pressuring refugees to return but also as an unwitting stooge of the Myanmar Government, tricked by its narrative of transformation:

"UNHCR share news that everything is very good but actually it is not. Myanmar Government is also saying to Rohingya people, you can come back too. This is propaganda. It is not true. We cannot go back. It is very obvious that we cannot go back. But we know the Myanmar Government does not tell the truth. They will show international groups the good things and after the people will suffer. We know the Myanmar Government will not do the right thing. We can never win against them. ${ }^{45}$

“These donors don't know the real situation in Burma. They think everything is ok but they don't know the real situation." 46

"There is a lot of pressure from UNHCR now about returns. Have they got a place where we can be safe?" ${ }^{47}$

Refugees saw the emphasis on return as accompanied by the removal of other options, particularly the possibility of remaining in camps in Thailand for much longer:

"Before, we never heard about return. Now many people come and say 'You have to think about your homeland. It is time to go back'. We hear this all the time. It is a big problem. We

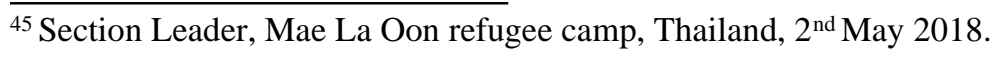

${ }^{46}$ Section Security, Mae La Oon refugee camp, Thailand,

${ }^{47}$ Section Leader, Mae La Oon refugee camp, Thailand, $1{ }^{\text {st }}$ May 2018
} 
cannot go back. We have nothing to go back to, no land. Also we cannot go back. So if we cannot go back and we cannot stay here it is a big problem." 48

“Of course we know that we cannot go back. It seems like we can't stay here either. They say that we can't stay a long time but don't give us a date either."49

"It is very challenging. Different people come to the camp and a lot of information is given about returns, by UNHCR and even by the Thai authorities. The community have a lot of questions. 'When will we go back?' They are asked, 'Where do you want to go back to?' But they can't answer. They are not from cities and their area is still under fighting. So they come to the Camp Committee and ask 'Where should we go? When do we have to go?"'50

Throughout all of these interviews there was a sense that the gulf between UNHCR's emphasis on return and refugees' own understanding of Myanmar's politics was unbridgeable. The resulting fear and uncertainty had become all-consuming for many people.

\section{Repatriation of Rohingya refugees from Bangladesh}

A generous interpretation might say that UNHCR's role in encouraging repatriation from Thailand has been simply political optimism, a miscalculation of the degree of transformation in Myanmar rather than anything more cynical. This explanation is not possible in relation to proposed repatriation of Rohingya refugees from Bangladesh. Rohingya have been persecuted

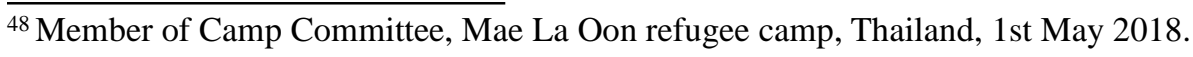

${ }^{49}$ Camp resident, Mae La Oon refugee camp, Thailand $3^{\text {rd }}$ May 2018.

${ }^{50}$ Member of Camp Committee, Mae La Oon refugee camp $4^{\text {th }}$ May 2018.
} 
in Myanmar for decades, with policies restricting travel, marriage, birth, voting and other rights establishing "a continuing situation of severe, systemic and institutionalized oppression from birth to death." ${ }^{51}$ Underpinning all of these policies has been the exclusion of Rohingya from recognition as a "national race" and related exclusion from citizenship and widespread statelessness. The cumulative effect of these policies was described by Zarni and Cowley in 2014 as a "slow-burning genocide". ${ }^{52}$ In August 2017, this became a highly visible genocide when devastating military attacks were unleashed on Rohingya villages in Rakhine State, killing an estimated 10,000 people and forcing more than 700,000 people to flee to Bangladesh. An United Nations Independent Fact-Finding Mission recommended the prosecution of several high-ranking Myanmar military officials for acts of genocide against Rohingya, and for crimes against humanity and war crimes committed in Rakhine, Kachin and Shan States. ${ }^{53}$

Despite this context of extreme violence, endemic persecution and entrenched impunity for the perpetrators, UNHCR and other international stakeholders cooperated with plans to repatriate Rohingya refugees from Bangladesh to Myanmar. In November 2017, Myanmar and Bangladesh signed an Arrangement on the Return of Displaced Persons from Myanmar in Bangladesh. This text arranged for return to commence in January 2018 for "residents of Rakhine State who have crossed over to Bangladesh after 9 October 2016 and 25 August 2017’, excluding around 300,000 Rohingya who were present in Bangladesh prior to that date. The agreement uses the language of international refugee law, recognising "the need for sustainable

\footnotetext{
${ }^{51}$ Human Rights Council (2018) Report of the independent international fact-finding mission on Myanmar, A/HRC/39/64, p6.

${ }^{52}$ Maung Zarni and A. Cowley (2014), The Slow-Burning Genocide of Myanmar's Rohingya, Pacific Rim Law and Policy Journal 23(3): 681-752.

${ }^{53}$ Human Rights Council (2018), Report of the Fact-Finding Commission, para 83, 87 and 92.
} 
and durable solutions" and agreeing that Myanmar and Bangladesh will "start the process of voluntary return in safety, security and dignity." There are no concrete provisions to ensure safety, security and dignity, with the text merely stating that returnees will return "voluntarily and safely to their own households and original places of residence" where "their freedom of movement will be allowed in conformity with the existing laws and regulations". 54

The repatriation agreement provoked international outcry. ${ }^{55}$ Refugees protested the repatriation and outlined preconditions for safe return, including restoration of citizenship and restoration of land. Despite this opposition, in June 2018 UNHCR and UNDP signed a Memorandum of Understanding to cooperate in repatriating Rohingya to Myanmar. The EU High Representative Federica Mogherini described the agreement as "an important and welcomed step" which the EU wanted "to be implemented without delay" and pledged five million euro towards its implementation. ${ }^{56}$ The Foreign Minister of Bangladesh responded to domestic and

\footnotetext{
${ }^{54}$ Arrangement on Return of Displaced Persons from Rakhine State Between the Government of the People's Republic of Bangladesh and the Government of the Republic of the Union of Myanmar, 23 November 2017,
} Article 2, emphasis added.

\footnotetext{
${ }^{55}$ Refugees International, ‘The Bangladesh-Myanmar Agreement for Rohingya Repatriation’, 17 Jan 2018 “it is baffling - and horrifying - that governments are discussing return of these victims to the very forces that perpetrated their oppression"; Minority Rights Group, 'Rohingya Repatriation must be voluntary and take place only once underlying issues are addressed by Myanmar Government', 16 January 2018; Physicians for Human Rights, 'Rohingya Repatriation Agreement Fails to Address Accountability and Safety Concerns', 17 January 2018; Human Rights Watch, 'Burma-Bangladesh Return Plan Endangers Refugees', 17 January 2018

${ }^{56}$ Statement by High Representative Federica Mogherini on the Signing of a Bilateral Repatriation Agreement, $23^{\text {rd }}$ November 2017.
} 
international criticism by saying, "Our only goal is to send the Rohingya back to their country, and there is no point in criticizing this agreement." 57

This process must be understood in light of a history of forced returns of refugees from Bangladesh to Myanmar, including in 1978 and 1992-1994..$^{58}$ These processes are explored in an unpublished report written for UNHCR's policy and evaluation unit, which was based on research in UNHCR's archive and offers unique insight into the agency's internal communications surrounding these repatriation processes. ${ }^{59}$ In 1978 , UNHCR was not a party to the repatriation agreement but had a role in monitoring the return process and the voluntariness of return. Refugees experienced physical violence and other coercion to return, including withdrawal of food aid. By the end of November 1978, the death rate in the camps was 8.5 times the Bangladeshi national average. ${ }^{60} \mathrm{UNHCR}$ was repeatedly notified of this by a staff nutritionist and through camp reports, yet took no action. ${ }^{61}$ Over the course of the

\footnotetext{
${ }^{57}$ Rohingya Repatriation Deal: What we Know, Dhaka Tribune 27 November 2017.

${ }^{58}$ J. Crisp (2018) We Must Not Repeat the Shameful History of Returning Rohingya Refugees, News Deeply https://www.newsdeeply.com/refugees/community/2018/01/17/we-must-not-repeat-the-shameful-history-ofreturning-rohingya-refugees; [accessed $21^{\text {st }}$ April 2020]; J. Crisp (2018) 'Primitive People': the untold story of UNHCR's historical engagement with Rohingya refugees, ODI Magazine available at https://odihpn.org/magazine/primitive-people-the-untold-story-of-unhcrs-historical-engagement-with-rohingyarefugees/ [accessed $21^{\text {st }}$ April 2020]

${ }^{59}$ (author unknown) Primitive People: the untold story of UNHCR's engagement with Rohingya refugees in Bangladesh, Unpublished Report by UNHCR PDES (copy on file with author of present article).

60 (author unknown) Primitive People, ibid, page 15.

${ }^{61}$ (author unknown) Primitive People, ibid, citing Cato Aall, Disastrous International Relief Failure: A report on Burmese Refugees in Bangladesh from May to December 1978, Disasters Vol. 3, no.4, pp. 429-34.
} 
repatriation, as many as 12,000 people in the camps died unnecessarily. ${ }^{62}$ Return conditions in Myanmar were also problematic. Violence occurred in return sites during 1978, and returnees faced serious difficulty in finding food and livelihoods. By the end of 1979, nearly 190,000 Rohingya refugees had been repatriated under this programme.

Conditions in Myanmar worsened for Rohingya during the 1980s and escalated to another phase of extreme persecution between 1991 and 1994, when more than 250,000 people crossed to Bangladesh. Again, a bilateral repatriation deal was quickly agreed and returns started in September 1992. UNHCR was initially critical but subsequently signed Memoranda of Understanding with Bangladesh (May 1993) and Myanmar (November 1993) and began to actively promote large-scale repatriation on the basis that repatriations were voluntary and conducted in conditions of safety. ${ }^{63}$ The MOUs were never made public but a statement issued by UNHCR at the time describes the agreement with Myanmar guaranteeing that returnees would be issued with appropriate identification papers and would enjoy the same freedom of movement as other Myanmar nationals, and granting UNHCR full access to all return sites. ${ }^{64}$ These guarantees were not fulfilled. An estimated 200,000 people were returned between 1992 and 1994, into the same conditions of insecurity and persecution.

These past processes established a template which has also been followed in the recent events: a bilateral repatriation agreement between Bangladesh and Myanmar which was negotiated

\footnotetext{
${ }^{62}$ Supra, page 22

${ }^{63}$ Supra, page 43.

${ }^{64}$ Burma: Memorandum on Repatriation, statement issued by the Information Section of the UNHCR in 1993, available at http://www.burmalibrary.org/reg.burma/archives/199401/msg00058.html [accessed 20 $0^{\text {th }}$ November $\underline{2019] .}$
} 
even while Rohingya villages were being destroyed in Myanmar, and a process which secured UNHCR cooperation despite failing to provide any guarantees of safety and security. Above all, these past processes show the complete disregard for the safety of returnees. ${ }^{65}$ The prevailing mentality within UNHCR in 1993 is reflected in a staff member's comment that, "These are primitive people. At the end of the day they will go where they are told to go." 66

In 2020, it is not clear that much has changed. UN independent experts have insisted that repatriation cannot be countenanced: "it is clear that Rohingya refugees in Bangladesh cannot return to Myanmar in the near future", "it is evident that Myanmar is not working to create conditions for return for the Rohingya but is engaging in a sustained campaign of violence, intimidation and harassment" 67 and, "in the current circumstances, returns are not possible." 68 UN staff, in contrast, have consistently supported the Myanmar Government and the plan for repatriation. The UN Secretary-General's Special Envoy to Myanmar (a post created by the General Assembly in 2017) has enthusiastically praised the smallest of gestures ("lauded the drafting of an information sheet for the refugees in Cox's Bazar") and accepted political statements at face value ("welcomed the stated willingness of the Rakhine leaders" to accept the refugees' return and "was satisfied to hear the Rakhine State Minister explain that the

\footnotetext{
${ }^{65}$ R. Rae, Special Envoy to the Prime Minister of Canada, (2018) Tell Them We're Human: What Canada and the World Can do About the Rohingya Crisis, Government of Canada.

${ }^{66}$ Crisp (2018), 'Primitive People', ibid.

${ }^{67}$ Office of the High Commissioner for Human Rights, End of Mission Statement by the Special Rapporteur on the Situation of Human Rights in Myanmar, 25 $5^{\text {th }}$ January 2019. Available at
} https://www.ohchr.org/EN/NewsEvents/Pages/DisplayNews.aspx?NewsID=24114\&LangID=E [accessed $21^{\text {st }}$ April 2020]

${ }^{68}$ Human Rights Council, Report of the Independent Fact-Finding Mission to Myanmar, ibid, para 112. 
'National Verification Cards are not for foreigners, but for people residing in Myanmar. It is a first step towards citizenship.” $)^{69}$

Repatriation of Rohingya had not started by April 2020. The Prime Minister of Bangladesh located the delay solely with Myanmar rather than with UNHCR or the international community: "The problem lies with Myanmar [..] Everybody wants the Rohingya people to return to Myanmar [...] Myanmar is not interested in taking them back."70 The Bangladesh Government proposed to relocate around 100,000 refugees from camps in Cox's Bazaar to an off-shore island, Bhasan Char. Low-lying, made of silt and sediment, and located miles from the Bangladesh coastline, this island is at extreme risk of flooding, cyclone and other natural disaster. UNHCR expressed support for it in principle and cooperated with the Bangladesh authorities in drawing up plans; though (for now at least) the proposed relocation has been shelved in the face of widespread resistance from refugees and human rights organisations. ${ }^{71}$

In contrast to refugees in Thailand, Rohingya refugees in Bangladesh are continuing to receive international support as a high visibility and high priority refugee population. However, this has not impeded the repatriation agreement, which was signed despite continuing violence in Myanmar and indeed despite international recognition of that violence as constituting the most

\footnotetext{
${ }^{69}$ Statement by the Special Envoy of the Secretary-General on Myanmar, "Dialogue will make Myanmar Stronger", 29"th January 2019.

${ }^{70}$ Sheikh Hasina quoted in Bangladesh, Myanmar Trade Blame Over Stalled Rohingya Repatriation, Radio Free Asia, $10^{\text {th }}$ June 2019.

${ }^{71}$ P. McPherson (2019) UN draws up plans to 'facilitate' Rohingya relocation to island, Reuters, 23 March 2019

UN official welcomes Rohingya relocation plan, Frontier Myanmar, 22 March 2019; B. Adams (2019) For

Rohingya, Bangladesh’s Bhasan Char 'Will Be Like a Prison’, Human Rights Watch 14 March 2019.
} 
serious crimes in international law. There is no doubt that Rohingya refugees must be able to return to Myanmar but this can only take place when their status in the country has been secured. The Rohingya case is particularly instructive as it offers a precise historical comparison for return without meaningful political change. In 1978 and again in the 1990s, thousands or even tens of thousands of people died as a direct result of the premature returns process, while an unknowable number of returnees were subjected to violence and persecution in the years that followed. This is a stark lesson that premature return costs lives, and that facilitating return in the absence of real legal and political reform will merely empower the Myanmar Government to commit further violence.

\section{Cessation for Chin refugees}

A third example of international actors encouraging premature return of refugees to Myanmar relates to Chin refugees. Chin State is in Western Myanmar, bordering Rakhine State, and people from this area have predominantly sought refuge in India and Malaysia. In June 2018, in close proximity to the extreme military onslaught in Rakhine State, UNHCR issued a declaration of cessation of refugee protection for the Chin refugee community, announcing that Chin refugees were no longer in need of international protection and their refugee status would be ended. The statement said (in part):

"An analysis of the political, social and security development in Chin State over the course of several years has determined that there are positive developments which are durable and sustainable in nature. While the situation in Myanmar is still fluid and unstable in parts of the country, the situation in Chin State is now stable and secure from a refugee protection perspective. Based on this UNHCR presumes that Chin 
refugees are safely able to avail themselves to the protection of the Myanmar Government and hence are no longer in need of international protection from UNHCR."72

Refugees were given the choice of accepting the declaration of cessation (in which case their refugee status would be removed at the end of 2019) or challenging the decision and asserting a continued need for international protection. Those who opted for the latter would have their refugee status immediately revoked while a case review was conducted. In the meantime, their UNHCR card was removed and a piece of paper declaring that the holder's case was under review given in its place. No time frame was given for the review process other than an "intention" to complete it by December 2019. This was particularly problematic because although UNHCR refugee registration is not officially recognised by the Malaysian

Government, UNHCR cards have strong informal protection value and card-holders are largely insulated from the widespread arrest, detention, caning and deportation that is inflicted upon undocumented migrants. ${ }^{73}$ Implementation of cessation began in Malaysia in August 2018 (affecting 16,000 registered Chin refugees and 35,000 asylum seekers) and Delhi in December 2018 (affecting 5000 registered refugees). The decision to end international refugee protection for Chin was justified in terms of Myanmar's transition and transformation. In 2018, UNHCR's Representative in Malaysia, Richard Towle, commented, "We should be welcoming, not condemning the changes in a country that allow people to think about going home. The

\footnotetext{
$\overline{72}$ The cessation statement was circulated to the refugee community and not made available through UNHCR media communications. Much of the statement is reprinted in S. B. Pisharoty (2018), UNHCR to cancel refugee status of Chins of Myanmar, The Wire, 30th June 2018.

${ }^{73}$ K. McConnachie (2019) Securitization and Community-based protection among Chin refugees in Kuala Lumpur, Social \& Legal Studies 28(2): 158-78.
} 
objective is to get people back to their communities, and the cultures that they know and love." 74

The 1951 Refugee Convention recognises the possibility of ending refugee status where there is no longer a need for international protection but sets a high threshold for doing so: "when the circumstances in connection with which he has been recognised as a refugee have ceased to exist." 75 This is a deliberately high threshold, reflecting the life-or-death consequences of removing refugee status. UNHCR policy guidance has reinforced the importance of a strict interpretation of this standard, ${ }^{76}$ with the Guidelines on Cessation (2003) indicating that the threshold might be satisfied where there is substantial and fundamental change that is enduring and where effective protection has been restored. UNHCR's statement of cessation for Chin refugees used this terminology ("positive developments which are durable and sustainable in nature") but was announced only months after the Myanmar army had committed widespread international crimes in Rakhine State, which is directly adjacent to Chin State. The cessation declaration also contravened UNHCR guidance by applying to a single geographical region

\footnotetext{
${ }^{74}$ S. Chow (2018) Refugees No More, R. AGE Malaysia, available at https://www.rage.com.my/refugeesnomore/ [accessed 20 ${ }^{\text {th }}$ April 2020]

${ }^{75}$ Article 1(C)(5) Convention Relating to the Status of Refugees (1951).

${ }^{76}$ UNHCR Executive Committee Conclusion No. 69, 'Cessation of Status' (1992) and UNHCR Guidelines on Cessation 2003 explain that a decision to declare cessation should be objective and verifiable, should be based on the general human rights situation and drawing on information from specialist bodies such as UNHCR, foreign embassies, media and academics. The declaration and its implementation should be public and transparent, including refugees, NGOs and UNHCR.
} 
and leaving those affected by the decision with uncertain status. ${ }^{77}$ Finally, it is significant that the cessation of international protection for Chin refugees was apparently a unilateral decision by UNHCR, without pressure from Malaysia or India (the states hosting Chin refugees). A new Government was elected in Malaysia in 2018; the first new government in 61 years. Its election campaign had emphasised a pledge of human rights reforms, including better treatment of refugees. Successive Indian Governments had historically adopted a position of benign neglect to Chin refugees (who are overwhelmingly Christians), offering little direct assistance but also not insisting they return to Myanmar. In declaring cessation for Chin refugees, UNHCR was taking a harder line than the Malaysian and Indian Governments, making this a truly “unnecessary cessation". ${ }^{78}$

The cessation decision was lifted on $14^{\text {th }}$ March 2019, after nine months of intense stress, anxiety and hardship for Chin refugees. The decision to lift cessation was as sudden as the decision to impose it. A UNHCR press release described the reversal as based on "new reports and assessments which did not support its original conclusion of fundamental and durable changes" and "noted specific concerns raised by the Chin community and civil society organizations." 79 The press release stated that "No Chin refugee had lost their refugee status" as a result of the cessation declaration. This implies that the declaration was harmless, which was certainly not the case. For almost a year, Chin refugees were in a sustained state of fear

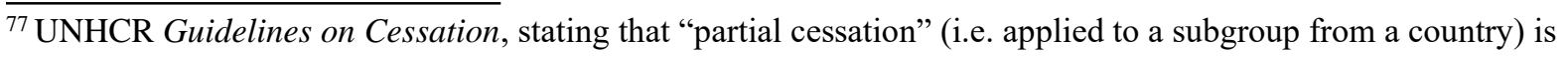
possible but that "changes in the country of origin affecting only part of the territory should not in principle, lead to cessation of refugee status."

${ }^{78}$ Elroi Yee (2019) ‘An Unnecessary Cessation', The Star 24 ${ }^{\text {th }}$ March 2019.

${ }^{79}$ UNHCR (2019) UNHCR says ethnic Chin refugees may require continued international protection as security situations worsens in Myanmar. 14 ${ }^{\text {th }}$ March 2019.
} 
and panic at having their refugee status removed. People made irreversible choices based on this decision, including, tragically, several cases of suicide. ${ }^{80}$

\section{Commonalities across contexts}

At the time of writing (April 2020) mass repatriation had not yet been implemented for refugees from Myanmar but the promotion of return has inflicted lasting consequences. In Thailand, Malaysia and India, international acceptance that repatriation is feasible and desirable has resulted in withdrawal of funding and services to refugees and a weakening of refugee-led organisations. There have also been consequences for refugees' security, as their status in hosting countries was made less stable. This was particularly dangerous in Malaysia, where refugees who challenged the declaration of cessation had their refugee status removed until their case was resolved, and were accordingly much more vulnerable to arrest, detention, caning and even deportation. In Thailand, food rations and services have been reduced for several years, which is likely to have lasting consequences for children's education and health.

Refugee status exists to provide surrogate protection in the event of a failure of protection by the state of nationality. For refugees from Myanmar, the focus on repatriation as the only option has been accompanied by a removal of other durable solutions options, either explicitly (as in the case of refugees in camps in Thailand or Chin refugees in Malaysia and India) or implicitly (in the case of the Rohingya). Refugees are unable to return safely but afraid that they will no longer be permitted to live as refugees either. This raises serious questions about compliance with UNHCR's international standards for repatriation to be voluntary, conducted in safety and

\footnotetext{
${ }^{80}$ I. Kumar and N. Raja (2019) Reclaiming Refugee Status: The Arduous Journey of Chin Refugees in India. Refugee Law Initiative 12 ${ }^{\text {th }}$ April 2019.
} 
with dignity. ${ }^{81}$ It has also been immensely damaging for refugees. In Bangladesh, the repatriation agreement "caused high levels of fear and anxiety amongst the already traumatised refugee population in Cox's Bazar, and led to refugees going into hiding or even attempt to take their own lives to avoid being forced to return to Myanmar." 82 Similarly in Thailand and Malaysia, community organisations report rising mental health concerns and an increase in suicides related to anxiety, uncertainty and fear of return..$^{83}$

Another consistent thread across the contexts is that decisions for refugees' futures have been taken externally and driven in particular by international agencies and donors. ${ }^{84}$ Refugee committees in Thailand were not consulted by UNHCR in designing and implementing "facilitated voluntary repatriation". Chin refugees and community organisations were not consulted before UNHCR declared cessation of their refugee status. Rohingya refugees and their representatives in Bangladesh have not been able to participate in decisions about their future. Despite their formal exclusion, refugees in all three cases discussed here have persistently asserted a political voice, using any and every mechanism available to them, including community-based organisations, diaspora organisations and international media. Refugee organisations have argued for "nothing about refugees without refugees", and clearly identified their needs and priorities in return, including legal status and citizenship (particularly

\footnotetext{
${ }^{81}$ Crisp and Long (2018), ibid, note 16 ; Crisp (2018), ibid note 42.

${ }^{82}$ Human Rights Council (2019) Report of the Special Rapporteur on the situation of human rights in Myanmar (A/HRC/40/68)

${ }^{83}$ S. Chow (2018), Refugees No More, R.AGE Malaysia, https://www.rage.com.my/refugeesnomore-chin/; Progressive Voice (2019) There is No One Who Does Not Miss Home: A Report on Protracted Displaced Due to Armed Conflicts in Burma/Myanmar.

${ }^{84}$ See M. Bradley, J. Milner, B. Peruniak (2019) Refugees' Roles in Resolving Displacement and Building Peace. Georgetown University Press.
} 
for Rohingya refugees) as well as provision for housing and sustainable livelihoods, gendered assistance and recognition of qualifications gained in exile. ${ }^{85}$ Refugees have advocated for legal change inside Myanmar (particularly in relation to land policy), have organised protests outside UNHCR offices and explained their position repeatedly to national and international media. These efforts have had little purchase. Failure to involve refugees in policy decisions is the norm in refugee situations but it is also significant, reflecting the reality that these processes are not really "about" refugees at all but are driven by other political interests and priorities.

\section{Refugee policy as border governance}

As shown above, refugees in camps in Thailand, Chin refugees in India and Malaysia and Rohingya refugees in Bangladesh have experienced consistent pressure to return despite continuing conflict and state violence in Myanmar. It is the contention of this article that this policy approach has not only had serious consequences for refugees but also for Myanmar's domestic politics. In this section I outline those consequences and argue that the premature promotion of return reproduces boundaries and hierarchies of power, constituting "border governance" at multiple scales.

Withdrawal of donor support from refugees and the promotion of return to Myanmar have been justified in terms of peacebuilding and transition. However, Myanmar's political

\footnotetext{
$\overline{85}$ There have been numerous publications and policy statements by refugee-led organisations, including a statement by the Karen Refugee Committee outlining 10 preconditions for repatriation; a set of Sectoral Policy Recommendations for the peace process (drafted with extensive input from refugees, IDPs and civil society) published by the Ethnic Nationalities Affairs Centre (http://www.burmaenac.org), and a 180-page research report published by 15 civil society organisations, Progressive Voice (2019), ibid.
} 
transformation remains fragile at best and forced migration has actually increased since political liberalisation began. ${ }^{86}$ Critical peacebuilding scholars have long recognised that international interventions in conflict-affected countries often fail to deliver on their ambitions, for reasons including a focus on economic growth rather than poverty reduction; an emphasis on state-centric reforms at the expense of political pluralism and hybridity; and programmes designed on the perceptions of political officials rather than the lived experiences of a wider population. ${ }^{87}$ Richmond and Pogodda have argued that:

"As has become obvious over time, statebuilding and liberal peacebuilding strategies fail to connect with their target populations. Instead, they end up buttressing problematic elites and their often chauvinistic, nationalistic, or personal interests." $" 88$

\footnotetext{
${ }^{86}$ Details of UNHCR's population of concern from Myanmar by year at http://popstats.unhcr.org/en/persons_of_concern.
}

${ }^{87}$ R. MacGinty (2015) Where is the local? Critical localism and peacebuilding, Third World Quarterly Vol. 36, no. 5, pp. 840-856; J. Öjendal, I. Schierenbeck, C. Hughes, eds (2017), The 'Local Turn' in Peacebuilding, Abingdon: Routledge; P. Firchow (2018), Reclaiming Everyday Peace, Cambridge: Cambridge University Press; R. MacGinty and P. Firchow (2016) 'Top-down and bottom-up narratives of peace and conflict', Politics Vol. 36, no. 3, pp. 308-323; R. Paris (2010), 'Saving liberal peacebuilding', Review of International Studies Vol. 36, pp. 337-365; D. Chandler (2006) Empire in Denial: The Politics of State-building, London: Pluto Press. MacGinty and Firchow found a consistent gap between top-down and bottom-up narratives of peace and a consistent pattern of elite narratives of peace and transition overriding local experiences of continued conflict and insecurity.

${ }^{88}$ O. Richmond and S. Pogodda (2016), Post-Liberal Peace Transitions: Between Peace Formation and State Formation, Edinburgh: Edinburgh University Press p3. 
Similar outcomes have been observed in diverse settings, including Rwanda, Somaliland, Sri Lanka and Afghanistan. ${ }^{89}$ In Myanmar, researchers have investigated the impact of international aid and trade in a variety of policy areas, including development and peacebuilding assistance, energy, transport rural development, peace and security and humanitarian aid. ${ }^{90}$ Refugee policy has not been analysed in this way, though the return of refugees can be read as a powerful political statement by international stakeholders, and one that risks (in Richmond and Pogodda's words) buttressing "chauvinistic, nationalistic or personal interests" against the needs of refugees and Myanmar's broader population.

The policies for return and repatriation of refugees outlined in this article challenge the central assumptions of repatriation as a restoration of citizenship, re-entry into a community of belonging and as an act of peacebuilding. Humanitarian standards for return in voluntariness, safety and dignity have not been met, yet international agencies and donors have apparently accepted return as the best and only option for refugees. Chimni has observed that "humanitarian factors do not shape the refugee policies of the dominant states in the

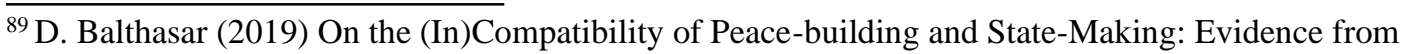
Somaliland, The Journal of Development Studies Vol. 55, no. 4, pp. 457-472; D. Beswick (2011) Aiding State Building and Sacrificing Peace Building? The Rwanda-UK Relationship 1994-2011 Third World Quarterly Vol. 32, no. 10, pp.1911-1930; O. Walton, 'Between War and the Liberal Peace: The Politics of NGO Peacebuilding in Sri Lanka, International Peacekeeping Vol. 19, no.1, pp.19-34; J. Goodhand and M. Sedra (2013) Rethinking liberal peacebuilding, statebuilding and transition in Afghanistan: an introduction, Central Asian Survey Vol. 32, no. 3, pp.239-254.

${ }^{90}$ T. Carr (2018), Supporting the Transition: Understanding Aid to Myanmar Since 2011. Asia Foundation; M. Pedersen (2012), Rethinking International Assistance to Myanmar in a Time of Transition, in N. Cheesman, M. Skidmore and T. Wilson, eds. Myanmar's Transition: Openings, Obstacles and Opportunities, Singapore:
} ISEAS, at pp. 271-287 (and other contributions to this volume). 
international system $[\ldots]$ non-humanitarian objectives are pursued by these actors from time to time behind the façade of humanitarianism." I argue that three "non-humanitarian objectives" are particularly evident in the pursuit of premature return of refugees to Myanmar. One such objective is almost certainly global border control, i.e. keeping refugees in their region of origin or returning them to their country of origin to ensure that they do not travel onwards to seek asylum elsewhere. There is a great deal of analysis of refugee outflows as a challenge to state borders, and of the evolving strategies of border control that seek to deter and prevent asylum-seeking. ${ }^{91}$ Much less attention has been paid to the ways in which refugee return can also serve purposes of border control and migration management, particularly when it is carried out as an ostensibly 'legitimate' repatriation rather than state push-backs or deportations. This argument is relevant to Myanmar but also to several other contexts where repatriation has recently been encouraged or carried out under the auspices of peacebuilding, including Somalis in Kenya, Afghans in Pakistan and Syrians in Lebanon. ${ }^{92}$

A second objective promoted by refugee return is to reinforce national borders between Myanmar and its surrounding states, reducing the porosity of these borders by reducing the likelihood of refugee protection. This dynamic seems to be more important for India and Bangladesh than Thailand and Malaysia (where the pressure for repatriation appears to have originated with UNHCR). Bangladesh has tolerated the presence of Rohingya from Myanmar for many years, though has in most cases refused to formally recognise them as refugees. At

\footnotetext{
${ }^{91}$ A very small sample of this literature includes N. De Genova, ed., The Borders of "Europe”: Autonomy of Migration, Tactics of Bordering. Durham: Duke University Press; E. Haddad, 2008. The Refugee in International Society, Cambridge: Cambridge University Press; R. Jones (2016), Violent Borders: Refugees and the Right to Move, London: Verso.

${ }^{92}$ See e.g. Crisp and Long, ibid. note 26.
} 
times of escalation and mass influx, however, the response has always been to push for repatriation at the first opportunity and as the only option. ${ }^{93}$ Similarly, India continues to host large populations of Tibetan and Tamil refugees as well as other ethnic groups from Myanmar, but has taken strong action to prevent any onward migration of Rohingya from Bangladesh, stationing thousands of soldiers along the India-Bangladesh border, pushing back or returning Rohingya who attempt to cross into Mizoram, and attempting to deport around 40,000 Rohingya who have been recognised as refugees by the UNHCR in New Delhi. Return of refugees is part of this wider portfolio of mechanisms to restrict asylum, and is another means for Bangladesh and India to assert their borders and insist that the Rohingya are Myanmar's responsibility. This aspect of border governance is also apparent from the text of the MyanmarBangladesh repatriation agreements, which not only outline the agreement to repatriate but reiterate general border control roles and responsibilities of the two countries. ${ }^{94}$

A third "non-humanitarian" objective is to define the boundaries of political transition by reinforcing an official narrative of peace and transition over lived realities of conflict, insecurity and continued persecution. As in Chimni's observation of 1990s repatriations, the promotion of refugee return has been accompanied by donor withdrawal from long-standing refugee communities and increased international investment in a rights-violating regime. However, conflict is not erased by renaming it "peace" or "transition", and premature repatriation can be understood both an act of violence in itself and a precipitating factor for other forms of violence. Furthermore, redefining peace has consequences for the balance of

\footnotetext{
${ }^{93}$ C. R. Abrar (1994), Repatriation of Rohingya Refugees, available at http://www.burmalibrary.org/docs21/Abrar-NM-Repatriation_of_Rohingya_refugees-en.pdf [accessed $21^{\text {st }}$
} April 2020]

${ }^{94}$ Arrangement on Return of Displaced Persons from Rakhine State, 23 November 2017, Article 17. 
power in political transition. International acceptance of repatriation supports a particular type of peace, a "victor's peace" that is aligned with the interests of Myanmar's government and military rather than other political actors. This risks reinforcing a unitary Myanmar State at the expense of ethnic and political pluralism and ultimately against the long-term interests of returning refugees.

Thus, policies for return of refugees to Myanmar can be understood as border governance in multiple dimensions: governing global borders by containing refugees in their region or country of origin; governing national borders between Myanmar and neighbouring countries; and governing political transition by bolstering a narrative of peacebuilding and development, regardless of the authenticity of those claims. Recognising these functions and consequences of repatriation highlights the importance of shifting the analytical frame of political transition to incorporate displacement, with a view to ensuring that policies for displaced people can be politically informed, contextualised and rooted in the preferences of refugees themselves. This analysis also highlights the importance of broadening understanding and analysis of repatriation, recognising that the effects of promoting refugee return begin even before mass returns have been carried out, and can reverberate far into the future. 